\title{
LABILE AND STABLE FRACTIONS OF SOIL ORGANIC MATTER UNDER MANAGEMENT SYSTEMS AND NATIVE CERRADO ${ }^{(1)}$
}

\author{
Cícero Célio de Figueiredo ${ }^{(2)}$, Dimas Vital Siqueira Resck ${ }^{(3)} \&$ Marco \\ Aurélio Carbone Carneiro ${ }^{(4)}$
}

\begin{abstract}
SUMMARY
Soil organic matter can be analyzed on the basis of the different fractions. Changes in the levels of organic matter, caused by land use, can be better understood by alterations in the different compartments. The aim of this study was to evaluate the effect of different management systems on the labile and stable organic matter of a dystrophic Red Latosol (Oxisol). The following properties were determined: total organic $\mathrm{C}$ and total N (TOC and TN), particulate organic C and particulate $\mathrm{N}$ (POC and PN), organic C and N mineral-associated (MOC and NM) and particulate organic C associated with aggregate classes (POCA). Eight treatments were used: seven with soil management systems and one with native Cerrado as a reference. The experiment was designed to study the dynamics of systems of tillage and crop rotation, alternating in time and space. The experimental design was a randomized block design with three replications. The soil samples were collected from five depths: 0-5, 5-10, 10-20, 20-30 and 30-40 cm. Changes in organic $\mathrm{C}$ by land use occurred mainly in the fraction of particulate organic matter $(>53 \mathrm{~mm})$. Proper management of grazing promoted increased levels of particulate organic matter by association with larger aggregates $(2-8 \mathrm{~mm})$, demonstrating the importance of the formation of this aggregate class for $\mathrm{C}$ protection in pasture.
\end{abstract}

Index terms: fractioning, particulate organic carbon, aggregates, no-tillage, pasture.

\footnotetext{
(1) Part of the doctoral thesis of the first author, developed at the Escola de Agronomia e Engenharia de Alimentos da Universidade Federal de Goiás - UFG. Received for publication in March 2009 and approved in March 2010.

(2) Professor at Universidade de Brasília - UnB. ICC Sul, Asa Norte, CEP 70910970 Brasília (DF). E-mail: cicerocf@unb.br

(3) Senior scientist of Embrapa Cerrados. E-mail: dimas.resck@bol.com.br

(4) Assistant Professor at UFG. Campus de Jataí/Laboratório de Solos, Rod. BR 364, km 192, CEP 75800-000 Jataí (GO). E-mail: carbonecarneiro@yahoo.com.br
} 


\title{
RESUMO: FRAÇÕES LÁBEIS E ESTÁVEIS DA MATÉRIA ORGÂNICA DO SOLO SOB SISTEMAS DE MANEJO E CERRADO NATIVO
}

\begin{abstract}
A matéria orgânica do solo pode ser estudada por meio de suas diferentes frações. Alterações dos teores de matéria orgânica, ocasionadas pelo uso do solo, podem ser mais bem compreendidas pelas mudanças nos seus diferentes compartimentos. Oobjetivo deste trabalho foi avaliar o efeito de diferentes sistemas de manejo nas frações lábeis e estáveis da matéria orgânica de um Latossolo Vermelho distrófico. Foram determinados: o carbono orgânico e o $N$ total do solo (COT e NT); o C e o $\mathrm{N}$ da matéria orgânica particulada (COP e NP); o C e o $\mathrm{N}$ orgânicos associados a minerais (COMe NM); e o Corgânico particulado associado a classes de agregados (COPA). Utilizaram-se oito tratamentos - sete com sistemas de manejo do solo e um com cerrado nativo - como referência. O experimento foi projetado para estudar a dinâmica de sistemas de preparo do solo e a rotação de culturas, com alternância no tempo e no espaço. O delineamento experimental utilizado foi o de blocos ao acaso com três repetições. As amostras de solo foram coletadas em cinco profundidades: 0-5, 5-10, 10-20, 20-30 e 30$40 \mathrm{~cm}$. Alterações nos teores de C orgânico pelo uso do solo ocorreram, principalmente, na fração particulada da matéria orgânica $(>53 \mu \mathrm{m})$. O manejo adequado de pastagens promoveu aumento dos teores de matéria orgânica particulada pela associação com agregados maiores (2-8 $\mathrm{mm})$, demonstrando que a formação dessa classe de agregados é uma importante forma de proteção de $C$ promovida pelas pastagens.
\end{abstract}

Termos de indexação: fracionamento, carbono orgânico particulado, agregados, plantio direto, pastagem.

\section{INTRODUCTION}

The conversion of native forests for cultivation is usually accompanied by a decline in organic matter and soil structure deterioration (Resck et al., 2008). In addition to changes in structure, organic matter reduction is associated with negative effects on nutrient concentrations (Ashagrie et al., 2007), water storage (Resck et al. 2008) and the emission of greenhouse gases (Lal, 2006).

Most studies use the content of total organic carbon (TOC) to quantify the stocks and changes in organic matter. In many cases, the changes resulting from land use are not duly reflected in TOC values (Roscoe \& Buurman, 2003), mainly due to the high C concentrations in stable and little variable mineral association (Lal, 2006).

The organic matter (SOM) is located in different compartments that have different recycling times and forms of protection (Duxbury et al., 1989). These pools or fractions may be arbitrarily established on the basis of location, composition or stability degree of the organic material (Baldock \& Nelson, 2000). Initially the SOM fractions were separated only by chemical means (Stevenson \& Cole, 1999). In recent decades, several techniques have been refined to separate the different fractions, trying to identify labile and stable fractions, and their location in the soil structure (Roscoe \& Machado, 2002). One such technique, the physical fractionation allows the separation of particulate organic matter (labile) composed of readily available material for decomposition by microbial attack, e.g., leaves, roots and animal remains
(Duxbury et al., 1989) and mineral-associated organic matter soil (stable) (Cambardella \& Elliott, 1992). These fractions have been used in studies involving the storage of SOM under different management systems (Bayer et al., 2004; Costa et al., 2004; Conceição et al., 2005; Vieira et al., 2007; Sá \& Lal, $2009)$, specifically on water-stable aggregates (Ashagrie et al., 2007). Has been emphasized to use these fractions as an attribute of soil quality (Conceição et al., 2005) and sensitivity as an indicator of changes caused by farming, when the passage of areas under natural vegetation for agriculture under conventional tillage (Ashagrie et al., 2007). Vieira et al. (2007) showed that particulate organic matter $(>53 \mathrm{~mm})$ can be used to determine the index that measures the lability of organic matter.

The influence of SOM on aggregate formation and stability is proven, although the existing fractions act differently in these processes (Baldock, 2002). The particulate fraction acts as a cementing agent, to stabilize macroaggregates and as intra-aggregate protection of the proper organic matter (Six et al., 2002). Costa et al. (2004) found differential contributions of total organic and particulate organic carbon (more labile) in the formation of soil aggregates.

In a study of Bayer et al. (2004), organic carbon in the particulate organic matter (POC) $(>53 \mu \mathrm{m})$ indicated management changes with greater sensitivity than TOC. In the said study, the C stock in mineral-associated organic matter (MOC) was not affected by the tillage systems. According to the authors, this is due to the advanced stage of humification and stability of the soil mineral fraction. 
The stratification rates of $\mathrm{C}$ and $\mathrm{N}$ in the particulate organic matter was higher in untilled soil profiles than in the mineral-associated organic matter (Sá \& Lal, 2009).

Research work on these organic matter fractions in Cerrado soils is still scarce, particularly with regard to protection processes in soil aggregates. With the increasing use of simulation models in studies of soil organic matter (Gjettermann et al., 2008), it is necessary to identify the different fractions and their forms of protection in tropical soils such as the Cerrado under native vegetation and management systems.

The aim of this study was to evaluate the effects of management systems on labile and stable organic matter fractions in a dystrophic Red Latosol in the Cerrado of the Central Plateau region.

\section{MATERIAL AND METHODS}

\section{Location and characteristics of the experimental area}

The study was carried out in the experimental field of Embrapa Cerrados, located in Planaltina, Distrito Federal (15 35 ' 30 " S, 47 ${ }^{\circ} 42^{\prime} 00$ " W, 1,014 m asl). According to the Köppen classification, the climate is Aw (tropical rainy), with dry winters, rainy summers and a rainless period during the rainy season, known as Indian summer (Adámoli et al., 1986).

All treatments were installed in a clay-textured, dystrophic Red Latosol (chemical and physical properties in Table 1).

\section{Management systems}

Eight treatments of a trial carried out in 1996 were selected, consisting of 16 treatments plus a plot with native Cerrado. The experiment was designed to study the dynamics of tillage systems and crop rotation, alternating in time and space.

The experiment was arranged in randomized blocks with three replications. Each plot covers an area of $22 \times 18 \mathrm{~m}$ (treatment description in Table 2).

From each plot, five deformed subsamples were randomly collected to form a composite sample, representing a replication of the treatment. This sampling was carried out in February 2008, during soybean flowering, in the layers 0-5, 5-10, 10-20, 2030 , and $30-40 \mathrm{~cm}$.

The soybean cultivar Conquista was planted on November 28, 2007. The spacing used was $45 \mathrm{~cm}$ between rows and 15 plants per meter. The seeds were inoculated with Bradyrhizobium, at a concentration of $0.5 \mathrm{~kg}$ of inoculum for each $40 \mathrm{~kg}$ of seeds treated with fungicide. The crop was fertilized with $400 \mathrm{~kg} \mathrm{ha}^{-1}$, of 0-20-20 NPK plus $50 \mathrm{~kg} \mathrm{ha}{ }^{-1}$ of FTE BR $12^{\circledR}$, composition: $1.8 \% \mathrm{~B}$, $0.8 \% \mathrm{Cu}, 3 \% \mathrm{Fe}, 2 \% \mathrm{Mn}, 0.1 \% \mathrm{Mo}$ and $9 \% \mathrm{Zn}$. The crop was harvested on April 18, 2008.

In the PAST treatment, Urochloa brizantha was planted with $45 \mathrm{~cm}$ spacing between rows and $25 \mathrm{~kg}$ seeds per hectare. The doses used each year were $60 \mathrm{~kg}$ ha-1 $\mathrm{P}_{2} \mathrm{O}_{5}, 60 \mathrm{~kg} \mathrm{ha}^{-1} \mathrm{~K}_{2} \mathrm{O}$ and $60 \mathrm{~kg} \mathrm{ha}^{-1} \mathrm{~N}$ (ammonium sulfate - $20 \% \mathrm{~N}$ ). The grass was cut by hand twice a year, once in February/March and a second time in July/August.

\section{Fractionation of organic matter}

After collection, the still friable soil samples were passed through a sieve of $8 \mathrm{~mm}$. Subsamples of these matrix samples were used for all analyses.

Table 1. Chemical and physical characterization of the soil studied ${ }^{(1)}$

\begin{tabular}{|c|c|c|c|c|c|}
\hline \multirow{2}{*}{ Property ${ }^{(2)}$} & \multicolumn{5}{|c|}{ Depth (cm) } \\
\hline & $0-5$ & $5-10$ & $10-20$ & $20-30$ & $30-40$ \\
\hline $\mathrm{C}$ org $\left(\mathrm{g} \mathrm{kg}^{-1}\right)$ & $18.8 \pm 3.9$ & $16.4 \pm 2.6$ & 15.3 & $12.7 \pm 1.4$ & $11.4 \pm 1.2$ \\
\hline $\mathrm{pH}\left(\mathrm{H}_{2} \mathrm{O}\right)$ & $5.2 \pm 0.4$ & $4.8 \pm 0.2$ & $4.7 \pm 0.2$ & $4.8 \pm 0.1$ & $4.8 \pm 0.1$ \\
\hline $\mathrm{Al}^{3+}\left(\mathrm{cmol}_{\mathrm{c}} \mathrm{kg}^{-1}\right)$ & $0.6 \pm 0.7$ & $0.8 \pm 0.5$ & $0.9 \pm 0.4$ & $0.9 \pm 0.3$ & $0.9 \pm 0.2$ \\
\hline $\mathrm{Ca}^{2+}+\mathrm{Mg}^{2+}\left(\mathrm{cmol}_{\mathrm{c}} \mathrm{kg}^{-1}\right)$ & $3.6 \pm 1.4$ & $2.6 \pm 1.3$ & $2.1 \pm 1.1$ & $1.4 \pm 0.8$ & $1.2 \pm 0.5$ \\
\hline $\mathrm{Ca}^{2+}\left(\mathrm{cmol}_{\mathrm{c}} \mathrm{kg}^{-1}\right)$ & $2.5 \pm 1.1$ & $1.9 \pm 1.0$ & $1.4 \pm 0.9$ & $0.9 \pm 0.6$ & $0.8 \pm 0.4$ \\
\hline $\mathrm{H}+\mathrm{Al}\left(\mathrm{cmol}_{\mathrm{c}} \mathrm{kg}^{-1}\right)$ & $6.8 \pm 2.5$ & $7.3 \pm 1.3$ & $7.0 \pm 1.1$ & $6.5 \pm 0.8$ & $6.0 \pm 0.9$ \\
\hline CTC $\left(\mathrm{cmol}_{\mathrm{c}} \mathrm{kg}^{-1}\right)$ & 10.93 & 10.2 & 9.23 & 7.98 & 7.26 \\
\hline $\mathrm{V}(\%)$ & 38 & 28 & 24 & 18.7 & 17.3 \\
\hline $\mathrm{N}\left(\mathrm{g} \mathrm{kg}^{-1}\right)$ & $1.8 \pm 0.3$ & $1.7 \pm 0.2$ & $1.6 \pm 0.2$ & $1.3 \pm 0.2$ & $1.3 \pm 0.2$ \\
\hline $\mathrm{P}\left(\mathrm{mg} \mathrm{kg}^{-1}\right)$ & $9.2 \pm 1.9$ & $11.8 \pm 5.3$ & $8.1 \pm 2.8$ & $3.3 \pm 1.3$ & $1.3 \pm 1.2$ \\
\hline $\mathrm{K}\left(\mathrm{mg} \mathrm{kg}^{-1}\right)$ & $211 \pm 71.7$ & $113.1 \pm 18.9$ & $50.8 \pm 22.9$ & $34.1 \pm 12.4$ & $22.7 \pm 9.7$ \\
\hline Bulk density $\left(\mathrm{kg} \mathrm{dm}^{-3}\right)$ & $1.09 \pm 0.08$ & $1.06 \pm 0.07$ & $1.04 \pm 0.05$ & $1.07 \pm 0.05$ & $1.07 \pm 0.06$ \\
\hline Clay $\left(\mathrm{g} \mathrm{kg}^{-1}\right)$ & $508 \pm 27$ & $505 \pm 26$ & $509 \pm 25$ & $517 \pm 25$ & $524 \pm 21$ \\
\hline Silt $\left(\mathrm{g} \mathrm{kg}^{-1}\right)$ & $89 \pm 20$ & $91 \pm 17$ & $87 \pm 13$ & $78 \pm 19$ & $77 \pm 19$ \\
\hline Sand $\left(\mathrm{g} \mathrm{kg}^{-1}\right)$ & $403 \pm 23$ & $404 \pm 22$ & $403 \pm 21$ & $405 \pm 27$ & $400 \pm 17$ \\
\hline
\end{tabular}

(1) Values correspond to the means and the standard deviation of the samples of each depth $(\mathrm{n}=24)$ in the treatments considered in this study. ${ }^{(2)}$ Properties evaluated by the methodology proposed by Embrapa (1997). 
Table 2. Description of the soil management systems

\begin{tabular}{|c|c|c|}
\hline Management system & Abbreviation & Description \\
\hline Heavy disc harrow & HD & Soil tillage with heavy disc harrow for soybean cultivation for 12 years. \\
\hline Disk plow & DP & Soil tillage with disk plow for soybean cultivation for 12 years. \\
\hline Minimum tillage (chisel plow) & $\mathrm{CHP}$ & $\begin{array}{l}\text { Tilling with disk plow in the first two years and moldboard plow } \\
\text { in the two following years. From the fifth year on, minimum } \\
\text { tillage with chisel plow was used, with biennial rotation of } \\
\text { maize and soybean. }\end{array}$ \\
\hline No tillage with biennial rotation & NT1 & $\begin{array}{l}\text { Tilling with disk plow in the first two years and moldboard plow } \\
\text { in the two following years. From the fifth year on, no-tillage } \\
\text { was used, with biennial rotation of maize and soybean. }\end{array}$ \\
\hline $\begin{array}{l}\text { No tillage with biennial rotation and } \\
\text { second growing season }\end{array}$ & NT2 & $\begin{array}{l}\text { Tilling with disk plow in the first two years and moldboard plow } \\
\text { in the two following years. From the fifth year on, no-tillage } \\
\text { was used, with biennial rotation in the summer of maize and } \\
\text { soybean, combined with legume in the second growing season } \\
\text { (pigeon pea in the first two years) and maize, respectively. }\end{array}$ \\
\hline No tillage with annual rotation & NT3 & $\begin{array}{l}\text { Tilling with disk plow in the first two years and moldboard plow } \\
\text { in the two following years. From the fifth year on, no-tillage, } \\
\text { with annual rotation of maize and soybean. }\end{array}$ \\
\hline Pasture & PAST & $\begin{array}{l}\text { Tilling with disk plow and cultivation of grass crops (rice and maize) } \\
\text { in the first two years and moldboard plow prior to pigeon pea } \\
\text { cultivation in the two following years. From the fifth year on, the } \\
\text { pasture grass Urochloa brizantha was used, without grazing. }\end{array}$ \\
\hline Cerrado & CER & $\begin{array}{l}\text { Área of Cerrado strictu sensu adjacent to the experimental area, } \\
\text { used as reference (control). }\end{array}$ \\
\hline
\end{tabular}

The organic matter was physically fractionated, according to Cambardella \& Elliott (1992), with adjustments in the sample weight used (Bayer et al., 2004; Bongiovanni \& Lobartini, 2006). The air-dried subsamples of the matrix were $2 \mathrm{~mm}$ sieved. Of these, $20 \mathrm{~g}$ were placed in plastic bottles (volume of $250 \mathrm{~mL}$ ) and $70 \mathrm{~mL}$ of sodium hexametaphosphate added at a concentration of $5.0 \mathrm{~g} \mathrm{~L}^{-1}$. The mixture was shaken for $15 \mathrm{~h}$ in a horizontal shaker, at 130 oscillations min $^{-1}$. After this process, the entire content of the vial was placed in a $53 \mu \mathrm{m}$ sieve and washed with a weak jet of distilled water. The material retained on the sieve, defined as total particulate organic matter $(>53 \mu \mathrm{m})$ was dried at $50^{\circ} \mathrm{C}$. After drying, the sample was ground in a porcelain mortar and passed completely through a $0.149 \mathrm{~mm}$ sieve. Then aliquots were weighed and analyzed for their $\mathrm{C}$ and $\mathrm{N}$ contents, representing the particulate organic carbon (POC) and $\mathrm{N}$ in particulate organic matter $(\mathrm{PN})$.

An aliquot of the $2 \mathrm{~mm}$ sieved subsample was ground in a porcelain mortar and passed through a $0.149 \mathrm{~mm}$ sieve. Subsequently, this material was used for analysis of total organic C (TOC) and total N (TN) of the total sample (bulk sample). Carbon and $\mathrm{N}$ of mineral-associated organic matter (MOC and MN, respectively) were calculated as the difference between
TOC and POC (for MOC) and between TN and PN (to $\mathrm{MN})$.

A subsample of $100 \mathrm{~g}$ of the matrix sample $(<8 \mathrm{~mm})$ was used to determine the aggregate size classes for the five depths of eight treatments, performed according to Embrapa (1997). After separation, three classes (2-8 mm 0.5-1 mm; 0.106$0.25 \mathrm{~mm}$ ) were chosen to determine the carbon and $\mathrm{N}$ fractions. Of the samples from each class, a portion was used to fractionate the organic matter. The methodology described above was applied to separate particulate organic matter.

At the end, the levels of carbon and N, particulate and mineral-associated, present in the three aggregate classes were determined as follows: POCA1 particulate organic carbon of 2-8 mm; POCA2 particulate organic carbon of $0.5-1 \mathrm{~mm}$; POCA3 particulate organic carbon of $0.106-0.25 \mathrm{~mm}$; PN1 $\mathrm{N}$ in particulate organic matter of $2-8 \mathrm{~mm} ; \mathrm{PN} 2-\mathrm{N}$ in particulate organic matter of $0.5-1 \mathrm{~mm}$; PN3 - N in particulate organic matter in class $0.106-0.25 \mathrm{~mm}$.

\section{Determination of aggregate size classes}

To determine the class distribution of water-stable aggregates $100 \mathrm{~g}$ soil were used from each sample, 
which were pre-moistened by capillary action when placed on the vertical oscillation device on a set of sieves with $2.00,1.00,0.50,0.25$, and $0.106 \mathrm{~mm}$ in diameter, as described by Embrapa (1997). After $30 \mathrm{~min}$, the material retained in each sieve was transferred by means of water-jets to aluminum pots, and oven-dried at $60^{\circ} \mathrm{C}$ for $72 \mathrm{~h}$ for later weighing. Based on the values of the mass and the known water content of soil samples submitted for analysis, the percentage of aggregates retained in the five sieves was quantified. The mean weight diameter (MWD) was calculated, according to Embrapa (1997), by the equation:

$$
D M P=\sum_{i=1}^{n}\left(x_{i} \cdot w_{i}\right)
$$

where $\mathrm{xi}=$ mean diameter of aggregate classes, wi = proportion of each class in relation to the total.

\section{Carbon and nitrogen analysis}

Analyses of total carbon and total $\mathrm{N}$ and total particulate fractions in aggregate size classes and bulk sample were carried out by dry combustion in a CHNS elemental analyzer (model PE 2400 Series II CHNS/ O, PerkinElmer, Norwalk, USA), using approximately $20 \mathrm{mg}$ of previously homogenized and sieved material. The material was digested in the closed combustion chamber at $900{ }^{\circ} \mathrm{C}$. Due to the absence of mineral carbon in the soil studied, the total carbon, determined by the methodology described, corresponds to the total organic carbon (TOC) of the samples.

\section{Statistical analysis}

The variables in the soil profiles from different management systems were compared by polynomial regression models using the program "Profile" (Colwell, 1978) for statistical significance/ differentiation of the treatments, based on analysis of variance of the variables of an orthogonal polynomial regression, where y represents the soil properties (TOC, POC, MOC, TN, PN, MN, POCA1, POCA2, POCA 3 and MWD) and $x$ represents the values at the depths considered in this study. The variables $\mathrm{p}_{0}, \mathrm{p}_{1}$, $\mathrm{p}_{2}$, and $\mathrm{p}_{3}$, independent from each other, were estimated for each sample replication, considering the midpoints of the sampled layers: $2.5 \mathrm{~cm}(0-5 \mathrm{~cm})$, $7.5 \mathrm{~cm}(5-10 \mathrm{~cm}) 15 \mathrm{~cm}(10-20 \mathrm{~cm}) 25 \mathrm{~cm}(20-30 \mathrm{~cm})$ and $35 \mathrm{~cm}(30-40 \mathrm{~cm})$, and comparing these parameters with the $t$ test at $5 \%$. The orthogonal polynomial regression model $\mathrm{y}=\mathrm{p}_{0}+\mathrm{p}_{1} \mathrm{x}_{\mathrm{L}}+\mathrm{p}_{2} \mathrm{x}_{\mathrm{Q}}+$ $\mathrm{p}_{3} \mathrm{x}_{\mathrm{C}}$ was used, where $\mathrm{p}_{0}$ represents the average treatment effect on the profile and the regression variables $\mathrm{p}_{1}, \mathrm{p}_{2}$ and $\mathrm{p}_{3}$ represent the amount and direction (sign) of each linear quadratic and cubic trend of the contents of the variables analyzed at each depth $(\mathrm{cm})$, respectively. The values of XL, XQ and $\mathrm{XC}$ refer, respectively, to the linear, quadratic and cubic coefficient of the orthogonal polynomials for interpolation, obtained by a program written in
Fortran language (Colwell, 1978). A non-orthogonal regression $\hat{y}=b_{0}+b_{1} x+b_{2} x_{2}+b_{3} x_{3}$ was also used, where $b_{0}, b_{1}, b_{2}$ and $b_{3}$ are interdependent and represent, respectively, the estimators of the parameters for the intercept and the linear, quadratic and cubic effects to calculate estimates of the final values of the variables considered for depth $\mathrm{x}(\mathrm{cm})$.

The profile analysis was used in this study because it allows monitoring the dynamics of different variables in the soil profile. The multivariate $\mathrm{F}$ test was used to compare the non-orthogonal regression models for the variable POC in all treatments.

\section{RESULTS AND DISCUSSION}

The values in table 3 represent the mean effects of the variables TOC, POC, POC, and MOC: TOC in the soil profile $\left(\mathrm{p}_{0}\right)$. The soil management systems differed in levels of total organic, particulate and mineral-associated carbon and in the relationship particulate organic C: total organic $\mathrm{C}$. The TOC values were highest (21.0, 20.9 and $20.8 \mathrm{~g} \mathrm{~kg}^{-1}$, respectively) in the CER, PAST and NT1 systems (Table 3). In areas close to this study, results for TOC levels (Ferreira et al., 2007) and TOC pool were similar (Corazza et al., 1999; Jantalia et al., 2007), although $\mathrm{C}$ values were lower in systems with annual soil tillage. Rangel \& Silva (2007) also found equal TOC values under pasture and native forest, which were higher than in tilled systems.

Table 3. Comparison of parameter $p_{0}$ of the regression $y=p_{0 M}+p_{1} x_{L}+p_{2} x_{Q}+p_{3} x_{C}$ for total organic carbon (TOC), particulate organic carbon (POC) and mineral-associated organic carbon (MOC) and the ratio particulate organic carbon: total organic carbon (POC:TOC) in eight soil management systems

\begin{tabular}{|c|c|c|c|c|}
\hline \multirow{2}{*}{ System } & \multicolumn{4}{|c|}{ Parameter $\mathbf{p}_{0}$} \\
\hline & $\operatorname{TOC}^{(* *)}$ & $\operatorname{POC}^{(* *)}$ & $\operatorname{MOC}^{(*)}$ & POC:TOC ${ }^{(* *)}$ \\
\hline & \multicolumn{3}{|c|}{$\mathrm{g} \mathrm{kg}^{-1}$} & $\%$ \\
\hline $\mathrm{HD}^{(2)}$ & $19.3 \mathrm{~b}^{(1)}$ & $5.58 \mathrm{bc}$ & $13.5 \mathrm{abc}$ & $25 \mathrm{~cd}$ \\
\hline $\mathrm{DP}$ & $18.5 \mathrm{bc}$ & $3.35 \mathrm{c}$ & $17.5 \mathrm{a}$ & $19 \mathrm{~d}$ \\
\hline $\mathrm{CHP}$ & $17.8 \mathrm{c}$ & $3.55 \mathrm{c}$ & $13.9 \mathrm{abc}$ & $25 \mathrm{~cd}$ \\
\hline NT1 & 20.8 & $5.06 \mathrm{bc}$ & $12.8 \mathrm{bc}$ & $33 \mathrm{bc}$ \\
\hline NT2 & $18.8 \mathrm{bc}$ & 4.60 & $14.2 \mathrm{ab}$ & $23 \mathrm{~cd}$ \\
\hline NT3 & $18.8 \mathrm{bc}$ & $3.97 \mathrm{c}$ & 14. $7 \mathrm{ab}$ & $21 \mathrm{c}$ \\
\hline PAST & 20.9 a & $10.16 \mathrm{a}$ & $10.4 \mathrm{c}$ & $48 \mathrm{a}$ \\
\hline CER & $21.0 \mathrm{a}$ & $8.05 \mathrm{ab}$ & $11.6 \mathrm{bc}$ & $39 \mathrm{ab}$ \\
\hline
\end{tabular}

(1) Values followed by the same letter in the column did not differ significantly from each other in the t test at $5 \%$. ${ }^{(2)}$ See description for Table $2 .{ }^{*}$ : significant at $5 \%$; **: significant at $1 \%$ by the $\mathrm{F}$ test. 
Among the agricultural managements, TOC was highest in NT1, exceeding also other conservation systems (CHP, NT2 and NT3). These results indicate differentiated forms of $\mathrm{C}$ accumulation in the soil, depending on the dynamics of the management systems as related to crop rotation and tillage, particularly for no-tillage, under the soil and climatic conditions of the Cerrado (Resck et al., 2008).

The $\mathrm{C}$ content in particulate organic matter, expressed as the mean POC value in the profile $\left(\mathrm{p}_{0}\right)$, ranged from $3.4 \mathrm{~g} \mathrm{~kg}^{-1}$ in the system under disk plow to $10.2 \mathrm{~g} \mathrm{~kg}^{-1}$ under grazing. It was observed that recycling of particulate organic matter from pasture was slower than from wheat residues (Cambardella \& Elliot, 1992). This fact, coupled with the large amount of roots produced by grasslands, may explain the high POC levels in this system. Pastures represent an option to increase $\mathrm{C}$ sequestration in the tropics, mainly due to the aggressive root system, where rhizodeposition occurs and the roots are constantly renewed (Lal, 2006; Salton et al., 2008), working as a system of soil $\mathrm{C}$ accumulation and recovery (Corraza et al., 1999; Resck et al., 2008). Since this potential is usually determined based on TOC values (Corazza et al., 1999), care must be taken regarding the management of these pastures, considering the high presence of particulate organic matter. For being more labile (Baldock \& Nelson, 2000 ), this organic matter $\mathrm{C}$ fraction may be quickly decomposed, thus constituting a fragile $\mathrm{C}$ reserve in the soil. A decrease of this $\mathrm{C}$ fraction could mean increased $\mathrm{CO}_{2}$ emissions. In degraded pastures, reductions of $36 \%$ in labile $\mathrm{C}$ were found in comparison with secondary forest (Portugal et al., 2008). According to Lal (2006), soil C losses are fast and sharp, whereas gains are slow and unsteady.

A comparative analysis of organic matter fractions showed different intensities for changes in $\mathrm{C}$ levels (Table 3). Excluding the PAST system and considering the average of the other managed systems, the reduction in organic $\mathrm{C}$ content was only $9.5 \%$ when converting natural Cerrado into another system $\left(\mathrm{CER}=21.0 \mathrm{~g} \mathrm{~kg}^{-1}\right.$; average of the other systems $=$ $\left.19.3 \mathrm{~g} \mathrm{~kg}^{-1}\right)$. When particulate organic matter is compared likewise, the mean POC levels in the profile drop by almost half (46.0\%). Using pasture as reference, this decrease reaches $57.0 \%$. These results demonstrate that $\mathrm{C}$ loss caused by cultivation on Cerrado soils occur in the particulate organic matter fraction. Similar but smaller losses were found in southern Brazil (Sá \& Lal, 2009).

The participation of POC in the TOC (POC: TOC) levels ranged from $19.0 \%$ (DP) to $48.0 \%$ (PAST), considering the average values in the profile $(0-40 \mathrm{~cm})$. This participation ranged from 18.0 to $39.0 \%$ in native pasture and managed systems, respectively, in Canada (Cambardella \& Elliot, 1992), and from 15.3 to $30.5 \%$ in undisturbed and upturned soil, respectively, in Argentina (Bongiovanni \& Lobartini,
2006). In the state of Rio Grande do Sul, Vieira et al. (2007) found variations from 9.5 to $17.7 \%$ in this ratio in untilled soils. In Red Latosol in Mato Grosso do Sul, the ratio for POC stocks ranged from 11 to $15 \%$ in the 0-20 cm layer, in no-tillage and conventional tillage systems only, respectively (Bayer et al., 2004).

In the DP system the MOC value was higher than in CER, PAST and NT1. In studies in the state of Parana, MOC levels were higher under conventional tillage with disk plow than under no-tillage and native forest (Sá \& Lal, 2009). These results demonstrate that, although more stable, this organic matter fraction can be influenced by the frequent use of implements such as disk plows. According to a study by Freitas et al. (2000), in Latosols in the Cerrado, the incorporation of residues in conventional tillage favored C storage in the organic-clayey compartment. Further studies should be performed to assess the participation of pyrogenic $\mathrm{C}$ in this organic matter fraction.

The non-orthogonal regression models of POC for the different systems in the soil profiles are shown in figure 1. High regression levels were considered, when significant at $5 \%(\mathrm{p} \leq 0.05)$. In general, in the surface layers, the systems can be divided into three groups: a) CER and PAST, with highest POC levels, b) notillage systems, with intermediate values, $c$ ) systems with annual soil tillage (HD and DP), even if minimal (CHP), with lowest levels. One strategy of increasing the $\mathrm{C}$ sequestration rate in tropical soils is the use of

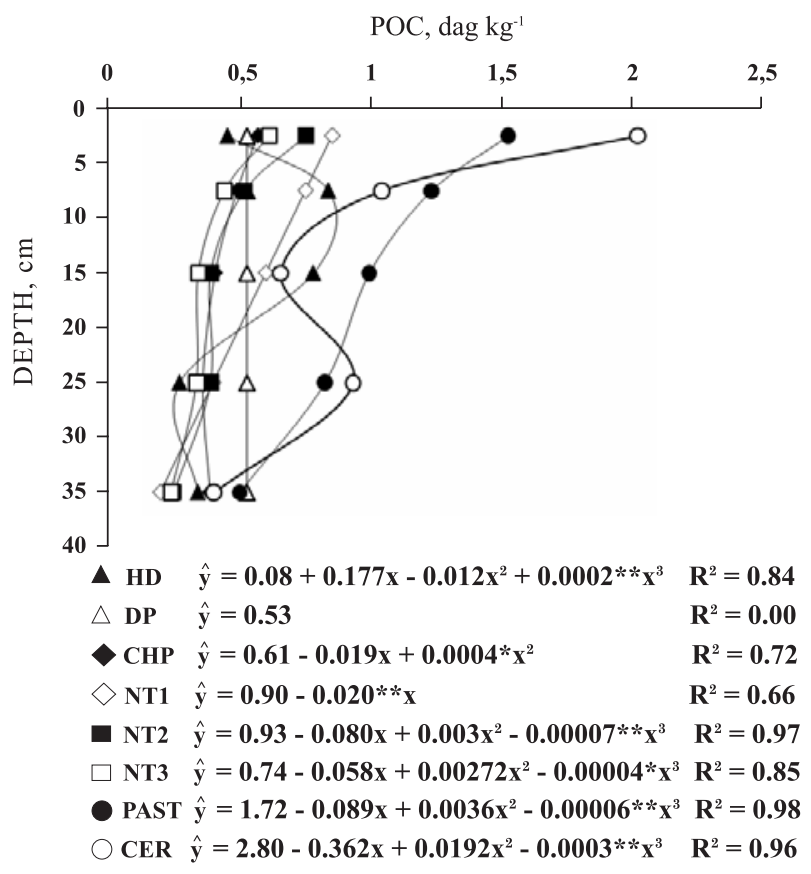

Figure 1. Distribution of levels of particulate organic carbon (POC) in the profiles of the different management systems according to the complete regression model of non-orthogonal polynomials. ${ }^{*}$ : significant at $5 \%{ }^{* * *}$ : significant at $1 \%$ by the $\mathrm{F}$ test. 
management systems that provide large amounts of biomass, especially with deep root systems (Lal, 2006). Based on the results presented, pasture is an appropriate option, similar to native Cerrado in the amount of biomass it provides the soil with.

Sá \& Lal (2009) studied the stratification rate of POC in soil profiles under management systems in the state of Parana. This rate is calculated by the ratio between the $\mathrm{POC}$ levels in the layer $0-5 \mathrm{~cm}$ and in the other layers (0-5 cm : 5-10 cm, for example). The results showed that no-tillage led to greater stratification of POC than the systems of conventional tillage. This demonstrates the ability of no-tillage of accumulating residues on the surface, mainly in regions with milder temperatures, but proves the limitation of this system in the distribution of organic matter across the soil profile exploited by crops (Resck, 1997).

In this study, this stratification was minimal in the no-tillage systems (Figure 1). Except for NT1, where POC declined linearly in the profile, significant cubic performance was observed in the systems NT2 and NT3, however, with a certain homogeneity in the profile, as a result of the dynamics of the tillage systems used in the first four years of the experiment, before introduction of no-tillage. The better distribution of POC in the profile under no-tillage (NT2 and NT3) confirms the observation of Resck (1997), that notillage should be used for the climate conditions of the Cerrado, however preceded by management systems including disk and moldboard plows, which promote chemical and physical corrections and increase organic matter and consequent changes in biological activity to a greater depth in the soil profile.

At $40 \mathrm{~cm}$ depth, POC is practically zero in all systems without annual soil tillage, similar to native Cerrado. This decrease in the pools of labile organic matter in undisturbed subsurface systems is due to the transformations of abundant litter material and the gradient created in the soil profile (Sá et al., 2008). The frequent use of agricultural implements for soil preparation, such as disk plows (DP) and moldboard plow, and even, under certain conditions, heavy disc harrow (HD), can raise the POC levels in depth (Figure 1).

Multivariate $\mathrm{F}$ values were used to compare the regressions of $\mathrm{POC}$ in the profiles of the treatments (Table 4). It appears that they were only significant between models of no-tillage systems (NT2 and NT3), PAST and CER, demonstrating similarity in form of distribution of the particulate organic matter in the profile between the systems without annual soil tillage. It should be noted that among the no-tillage systems, the multivariate $\mathrm{F}$ value for NT2 and NT3 was high (0.62), demonstrating that even being cubic distribution models, they have different shapes, reinforcing the curve behavior presented in figure 1 .

The C: $\mathrm{N}$ ratio is used as an indicator of organic matter quality (Stevenson \& Cole, 1999). In Table 5, this relationship is presented for soil organic matter (TOC: TN) and particulate organic matter (POC: PN).

Table 5. Comparison of the regression variable $p_{0} y=$ $p_{0 M}+p_{1} x_{L}+p_{2} x_{Q}+p_{3} x_{C}$ for the ratios total organic carbon: total nitrogen and particulate organic carbon: nitrogen of particulate organic matter under eight soil management systems

\begin{tabular}{|c|c|c|}
\hline \multirow{2}{*}{ System } & \multicolumn{2}{|c|}{ Parameter $\left(p_{0}\right)$} \\
\hline & COT:TN ${ }^{(*)}$ & POC:PN ${ }^{(* *)}$ \\
\hline $\mathrm{HD}^{(2)}$ & & \\
\hline $\mathrm{HD}$ & $17.1 \mathrm{bc}^{(1)}$ & $26.74 \mathrm{c}$ \\
\hline $\mathrm{DP}$ & $17.1 \mathrm{bc}$ & $13.60 \mathrm{~d}$ \\
\hline DHP & $18.8 \mathrm{a}$ & $32.90 \mathrm{bc}$ \\
\hline NT1 & $18.1 \mathrm{ab}$ & $25.27 \mathrm{c}$ \\
\hline NT2 & $16.1 \mathrm{c}$ & $34.60 \mathrm{bc}$ \\
\hline NT3 & $16.9 \mathrm{bc}$ & $29.55 \mathrm{c}$ \\
\hline PAST & $17.1 \mathrm{bc}$ & $47.78 \mathrm{a}$ \\
\hline CER & $17.4 \mathrm{abc}$ & $41.93 \mathrm{ab}$ \\
\hline
\end{tabular}

(1) Values followed by the same letter in the column did not differ significantly from each other in the t test at $5 \%$. ${ }^{(2)}$ See description for Table $2 .{ }^{*}$ : significant at $5 \%$; ${ }^{* *}$ : significant at $1 \%$ by the $\mathrm{F}$ test.

Table 4. Multivariate $\mathrm{F}$ values for comparison of the regression models of the variable POC between the treatments

\begin{tabular}{|c|c|c|c|c|c|c|c|}
\hline \multirow{2}{*}{ System } & \multicolumn{7}{|c|}{ Multivariate $F$ values } \\
\hline & HD & DP & CHP & NT1 & NT2 & NT3 & PAST \\
\hline \multicolumn{8}{|l|}{$\mathrm{HD}^{(1)}$} \\
\hline $\mathrm{DP}$ & $0.99^{\mathrm{ns}}$ & & & & & & \\
\hline $\mathrm{DHP}$ & $0.60^{\mathrm{ns}}$ & $0.48^{\mathrm{ns}}$ & & & & & \\
\hline NT1 & $0.49^{\text {ns }}$ & $0.76^{\mathrm{ns}}$ & $0.54^{\mathrm{ns}}$ & & & & \\
\hline NT2 & $0.74^{\mathrm{ns}}$ & $0.64^{\mathrm{ns}}$ & $0.36^{\text {ns }}$ & $0.82^{\mathrm{ns}}$ & & & \\
\hline NT3 & $0.61^{\mathrm{ns}}$ & $0.54^{\mathrm{ns}}$ & $0.40^{\mathrm{ns}}$ & $0.60^{\mathrm{ns}}$ & $0.62^{*}$ & & \\
\hline PAST & $0.46^{\mathrm{ns}}$ & $0.43^{\text {ns }}$ & $0.06^{\mathrm{ns}}$ & $0.69^{\text {ns }}$ & $0.04^{* * *}$ & $0.13^{* *}$ & \\
\hline CER & $0.53^{\mathrm{ns}}$ & $0.34^{\mathrm{ns}}$ & $0.33^{\text {ns }}$ & $0.71^{\mathrm{ns}}$ & $0.33^{\mathrm{ns}}$ & $0.17^{* *}$ & $0.72^{\mathrm{ns}}$ \\
\hline
\end{tabular}

(1) See description for Table 2. *: significant at $10 \% ; * *$ : significant at $5 \% ; * * *$ significant at $1 \%$; ns: non-significant by the $\mathrm{F}$ test. 
Considering the average behavior of the profile $\left(\mathrm{p}_{0}\right)$, the $\mathrm{C}$ : $\mathrm{N}$ ratio of particulate organic matter was higher than of soil organic matter, except in the DP system. In soil organic matter there was no difference in the C: $\mathrm{N}$ ratio (TOC: TN) between CER and the other systems. In the particulate organic matter however, the ratio was higher in CER than in the systems HD, DP, NT1, and NT3. Under pasture, the POC: PN ratio was higher than in the other management systems and did not differ from CER. This difference between PAST and the other systems can be explained by the residue type that enters the soil. While in the farming systems legumes such as soybean with low $\mathrm{C}: \mathrm{N}$ ratio are used, this ratio is high in tissues of pasture systems, which, when added to soil, decompose in less time (Moreira \& Siqueira (2002). In the case of soybean, the residues have high contents of soluble compounds and $\mathrm{N}$ and low contents of cellulose and ash, leading to a faster decomposition than of grasses (Moreira \& Siqueira, 2002).

As in this study the levels of total $\mathrm{C}$ and associated minerals in the aggregate classes were not determined, only the participation of $\mathrm{POC}$ will be discussed in the process of soil aggregation.

The management systems showed different POC levels in the aggregate classes, assessed by the mean levels in the profile $\left(\mathrm{p}_{0}\right)$. In general, the highest POC levels for the systems were found in the $2-8 \mathrm{~mm}$ aggregates (POCA1) (Table 6). The POCA1 levels were highest in the PAST system, even higher than in CER. This was not repeated in the POCA2 values, demonstrating that the formation mechanism of larger aggregates $(2-8 \mathrm{~mm})$ in pastures involves the participation of particulate organic matter. In results of Ashagrie et al. (2007), the effect of cultivation was more pronounced in particulate organic matter associated with macroaggregates than in the fractions associated with microaggregates. The participation of POC proved to be the main mechanism of formation of larger aggregates from microaggregates (Jastrow, 1996). Zotarelli et al. (2007) found that, of the total C associated with aggregates, $79.0-90.0 \%$ was found in the mineral fraction.

For POCA2, there was little difference between the systems, showing that particulate organic matter is marginally modified by soil management. In this class, the POC values in the system with annual soil disturbance (DP) were equal to CER and exceeded those of no-tillage systems (NT1 and NT2). Since POC levels were low in the full sample (bulk sample) of DP (Table 3) and the mean aggregate diameter was small (Table 6), it was concluded that in this system, despite the break-up of aggregates by cultivation, particulate organic matter is protected in aggregates, mainly in the 1-2 mm class (POCA2). Furthermore, the aggregate break-up by tillage exposes POC to microbial attack, reducing its level, so POC is lost by biological oxidation and transformed into mineralassociated organic matter (Table 3).
The regression models were not significant $(p>0.05)$ for any of the estimator variables of POCA3. However, although not significant, the results indicate the minor participation of POC in the portion of microaggregates analyzed $(0.106-0.25 \mathrm{~mm})$, confirming the low POC concentrations in depth (Table 6).

The values of mean weight diameter (MWD), represented by the profile means $\left(\mathrm{p}_{0}\right)$ in the different systems showed that the systems could be grouped in three distinct groups according to the soil aggregate size: highest values in the CER and PAST systems (1, 84 and $1.85 \mathrm{~mm}$, respectively), intermediate under no-tillage (NT3, NT1 and NT2: 1.55, 1.41 and $1.34 \mathrm{~mm}$, respectively), and lowest in systems with annual soil tillage (DP, HD and CH: 1.18, 1.11 and $1.11 \mathrm{~mm}$, respectively) (Table 6). These results show the typical impact of tillage operations on the breakdown of stable aggregates, as reported by several authors (Freibauer et al., 1999; Ashagrie et al., 2007; Resck et al., 2008; Sá et al., 2008; Salton et al., 2008). The cultivation decreased the proportion of waterstable macroaggregates from 70 to $50 \%$, in comparison with natural forest, in a study of Ashagrie et al. (2007). In our study, compared to native Cerrado, cultivation with conventional tillage decreased the aggregate MWD by $38.4 \%$. The MWD value in permanent pasture was higher than in other management systems, including integrated farm and livestock systems (Salton et al., 2008). The fact that PAST did not differ from the CER system in aggregate size (MWD) (Table 6), but had a higher POCA1 level, shows that the direct relationship between POC and MWD is associated to $\mathrm{C}$ protection in PAST soil. A similar relationship was reported in a study of

Table 6. Comparison of parameter $p_{0}$ of the regression $y=p_{0 M}+p_{1} x_{L}+p_{2} x_{Q}+p_{3} x_{C}$ for particulate organic carbon in different classes and mean weight diameter (MWD) of aggregates under eight treatments

\begin{tabular}{lllll}
\hline \multirow{2}{*}{ System } & \multicolumn{4}{c}{${\text { Parameter }\left(\mathbf{p}_{0}\right)}$} \\
\cline { 2 - 4 } & POCA1 $^{(*)}$ & POCA2 $^{(*)}$ & POCA3 $^{(\mathrm{ns})}$ & MWD $^{(*)}$ \\
& & $\mathrm{P} \mathrm{kg}^{* 1}$ & $\mathrm{~mm}$ \\
\cline { 2 - 4 } & & & \\
HD & & & \\
DP & $6.00 \mathrm{de}^{(1)}$ & $4.5 \mathrm{ab}$ & 2.1 & $1.11 \mathrm{e}$ \\
DHP & $8.00 \mathrm{bc}$ & $5.4 \mathrm{a}$ & 2.1 & $1.18 \mathrm{e}$ \\
NT1 & $5.70 \mathrm{e}$ & $4.4 \mathrm{ab}$ & 1.7 & $1.11 \mathrm{e}$ \\
NT2 & $7.30 \mathrm{~cd}$ & $3.9 \mathrm{~b}$ & 1.9 & $1.41 \mathrm{bc}$ \\
NT3 & $5.40 \mathrm{e}$ & $4.2 \mathrm{ab}$ & 1.8 & $1.34 \mathrm{~cd}$ \\
PAST & $4.90 \mathrm{e}$ & $3.4 \mathrm{~b}$ & 1.6 & $1.55 \mathrm{~b}$ \\
CER & $10.9 \mathrm{a}$ & $4.2 \mathrm{ab}$ & 1.4 & $1.85 \mathrm{a}$ \\
& $8.80 \mathrm{~b}$ & $5.3 \mathrm{a}$ & 2.9 & $1.84 \mathrm{a}$
\end{tabular}

(1) Values followed by the same letter in the column did not differ significantly from each other in the t test at $5 \%$. ${ }^{(2)}$ See description for Table $2 .{ }^{*}$ : significant at $5 \% ;{ }^{* *}$ : significant at $1 \%$; ns: non-significant by the $\mathrm{F}$ test. 
Freibauer et al. (1999), where the dominant form of organic matter in the pasture was free particulate. These authors found that four years after converting native Cerrado into pasture, the MWD had remained the same, whereas cultivation with corn / soybean rotation led to a reduction in MWD. Lal (2006) argues that the ability to form aggregates is one of the factors affecting $\mathrm{C}$ sequestration rates in the soil.

\section{CONCLUSIONS}

1. Changes in organic $\mathrm{C}$ by land use occurred, mainly, in the particulate fraction $(>53 \mathrm{~mm}$ ) of organic matter.

2 . The use of suitably managed pastures, without grazing, led to increases in the levels of particulate organic matter and to the association with larger aggregates $(2-8 \mathrm{~mm})$.

3. The frequent use of disk plowing for soil tillage increased the levels of mineral-associated organic matter.

4. Under the soil and climate conditions of the Cerrado, the introduction of no-tillage systems preceded by a correction of soil chemistry and structure promoted a more uniform distribution of particulate organic matter in the profile.

\section{LITERATURE CITED}

ADÁMOLI, J.; MACEDO, J.; AZEVEDO, L.G. \& MADEIRA NETO, J. Caracterização da região dos Cerrados. In: GOEDERT, W.J. Solos dos Cerrados: Tecnologias e estratégias de manejo. Planaltina, Embrapa-CPAC; São Paulo, Nobel, 1986. p.33-74.

ASHAGRIE, Y.; ZECH, W.; GUGGENBERGER, G. \& MAMO, T. Soil aggregation, and total and particulate organic matter following conversion of native forests to continuous cultivation in Ethiopia. Soil Till. Res., 94:101$108,2007$.

BALDOCK, J.A. Interactions of organic materials and microorganisms with minerals in the stabilization of soil structure. In: HUANG, P.M.; BOLLAG, J.M. \& SENESI, N., eds. Interactions between soil particles and microorganisms: Impacts on the terrestrial ecosystem. Chichester, IUPAC, 2002. p.58-132. (Series on Analytical and Physical Chemistry of Environmental Systems, 8)

BALDOCK, J.A. \& NELSON, P.N. Soil organic matter. In: SUMNER, M.E., ed. Handbook of soil science. Boca Raton, CRC Press, 2000. p.25-84.

BAYER, C.; MATIN-NETO, L.; MIELNICZUK, J. \& PAVINATO, A. Armazenamento de carbono em frações lábeis da matéria orgânica de um Latossolo Vermelho sob plantio direto. Pesq. Agropec. Bras., 39:677-683, 2004.
BONGIOVANNI, M.D. \& LOBARTINI, J.C. Particulate organic matter, carbohydrate, humic acid contents in soil macroand microaggregates as affected by cultivation. Geoderma, 136:660-665, 2006.

CAMBARDELLA, C.A. \& ELLIOTT, E.T. Particulate soil organic-matter changes across a grassland cultivation sequence. Soil Sci. Soc. Am. J., 56:777-783, 1992.

COLWELL, J.D. Computations for studies of soil fertility and fertilizer requirements. Canberra, CSFRO Division of Soils, A.C.T. Australia Commonwealth Agricultural Bureau, 1978. 297p.

CONCEIÇÃO, P.C.; AMADO, T.J.C.; MIELNICZUK, J. \& SPAGNOLLO, E. Qualidade do solo em sistemas de manejo avaliada pela dinâmica da matéria orgânica e atributos relacionados. R. Bras. Ci. Solo, 29:777-788, 2005.

CORAZZA, E.J.; SILVA, J.E.; RESCK, D.V.S. \& GOMES, A.C. Comportamento de diferentes sistemas de manejo como fonte ou depósito de carbono em relação à vegetação de Cerrado. R. Bras. Ci. Solo, 23:425-432, 1999.

COSTA, F.S.; BAYER, C.; ALBUQUERQUE, J.A. \& FONTOURA, S.M.V. Aumento de matéria orgânica num Latossolo Bruno em plantio direto. Ci. Rural, 34:587-589, 2004.

DUXBURY, J.M.; SMITH, M.S. \& DORAN, J.W. Soil organic matter as a source and sink of plant nutrients. In: COLEMAN, D.C.; OADES, J.M. \& UEHARA, G., eds. Dynamics of soil organic matter in tropical ecosystems. Honolulu, University of Hawaii Press, 1989.

EMPRESA BRASILEIRA DE PESQUISA AGROPECUÁRIA EMBRAPA. Centro Nacional de Pesquisa de Solos. Manual de métodos de análise de solos. 2.ed. Rio de Janeiro, 1997. $212 \mathrm{p}$.

FERREIRA, E.A.B.; RESCK, D.V.S.; GOMES, A.C. \& RAMOS, M.L.G. Dinâmica do carbono da biomassa microbiana em cinco épocas do ano em diferentes sistemas de manejo do solo no Cerrado. R. Bras. Ci. Solo, 31:1625-1635, 2007.

FREIBAUER, A.; WESTERHOF, R.; AYARZA, M.A.; SILVA, J.E. \& ZECH, W. Short-term variation in aggregation and particulate organic matter under crops and pastures. In: THOMAS, R. \& AYARSA, M.A. Dynamics of soil organic matter and indicators of soil quality: Sustainable land manager for the Oxisoils of the Latin America Savannas. Cali, CIAT, 1999. p.77-88.

FREITAS, P.L.; BLANCANEAUX, P.; GAVINELLI, E.; LARRÉLARROUY, M. \& FELLER, C. Nível e natureza do estoque orgânico de Latossolos sob diferentes sistemas de uso e manejo. Pesq. Agropec. Bras., 35:157-170, 2000.

GJETTERMANN, B.; STYCZEN, M.; HANSEN, H.C.B.; VINTHER, F.P. \& HANSEN, S. Challenges in modelling dissolved organic matter dynamics in agricultural soil using DAISY. Soil Bio. Biochem., 40:1506-1518, 2008.

JANTALIA, C.P.; RESCK, D.V.S.; ALVES, B.J.R.; ZOTARELLI, L.; URQUIAGA, S. \& BODDEY, R.M. Tillage effect on C stocks of a clayey Oxisol under a soybean-based crop rotation in the Brazilian Cerrado region. Soil Till. Res., 95:97-109, 2007. 
JASTROW, J.D. Soil aggregate formation and the accrual of particulate and mineral-associated organic matter. Soil Biol. Biochem., 28:665-676, 1996.

LAL, R. Soil carbon sequestration in Latin America. In: LAL, R.; CERRI, C.C.; BERNOUX, M.; ETCHEVES, J. \& CERRI, E. Carbon sequestration in soils of Latin America. New York, Food Products Press, 2006. p.49-64.

MOREIRA, F.M.S. \& SIQUEIRA, J.O. Microbiologia e bioquímica do solo. Lavras, Universidade Federal de Lavras, 2002. 625p.

PORTUGAL, A.F.; JUCKSCH, I.; SCHAEFER, C.E.G.R. \& WENDLING, B. Determinação de estoques totais de carbono e nitrogênio e suas frações em sistemas agrícolas implantados em Argissolo Vermelho-Amarelo. R. Bras. Ci. Solo, 32:2091-2100, 2008.

RANGEL, O.J.P. \& SILVA, C.A. Estoques de carbono e nitrogênio e frações orgânicas de Latossolo submetido a diferentes sistemas de uso e manejo. R. Bras. Ci. Solo, 31:1609-1623, 2007.

RESCK, D.V.S.; FERREIRA, E.A.B.; FIGUEIREDO, C.C. \& ZINN, Y.L. Dinâmica da matéria orgânica no Cerrado. In: SANTOS, G.A.; SILVA, L.S.; CANELLAS, L.P. \& CAMARGO, F.O., eds. Fundamentos da matéria orgânica do solo: Ecossistemas tropicais e subtropicais. 2.ed. Porto Alegre, Metrópole, 2008. p.359-417.

RESCK, D.V.S. O plantio direto como alternativa de sistema de manejo e conservação do solo e da água na região dos Cerrados. In: CONGRESSO BRASILEIRO DE CIÊNCIA DO SOLO, 26., Rio de Janeiro. 1997, Anais. Rio de Janeiro, Embrapa-CNPS/CBCS, 1997. CD-ROM.

ROSCOE, R. \& BUURMAN, P. Tillage effects on soil organic matter dynamics in density fractions of a cerrado Oxisol. Soil Till. Res., 70:107-119, 2003.
ROSCOE, R. \& MACHADO, P.L.O.A. Fracionamento físico do solo em estudos da matéria orgânica. Dourados, Embrapa Agropecuária Oeste; Rio de Janeiro, Embrapa Solos, 2002. $86 \mathrm{p}$.

SÁ, J.C.M. \& LAL, R. Stratification ratio of soil organic matter pools as an indicator of carbon sequestration in a tillage chronosequence on a Brazilian Oxisol. Soil Till. Res., 103:46-56, 2009.

SÁ, J.C.M.; SÁ, M.F.M.; SANTOS, J.F. \& OLIVEIRA, A. Dinâmica da matéria orgânica nos Campos Gerais. In: SANTOS, G.A.; SILVA, L.S.; CANELLAS, L.P. \& CAMARGO, F.O., eds. Fundamentos da matéria orgânica do solo: Ecossistemas tropicais e subtropicais. 2.ed. Porto Alegre, Metrópole, 2008. p.443-461.

SALTON, J.C.; MIELNICZUK, J.; BAYER, C.; BOENI, M.; CONCEIÇÃO, P.C.; FABRÍCIO, A.A.; MACEDO, M.C.M. \& BROCH, D.L. Agregação e estabilidade de agregados do solo em sistemas agropecuários em Mato Grosso do Sul. R. Bras. Ci. Solo, 32:11-21, 2008.

SIX, J.; FELLER, C.; DENEF, K.; OGLE, S.M.; SÁ, J.C.M. \& ALBRECHT, A. Soil organic matter, biota and aggregation in temperate and tropical soils - effects of no-tillage. Agronomie, 22:755-775, 2002.

STEVENSON, F.J. \& COLE, M.A. Cycles of soils: Carbon, nitrogen, phosphorus, sulfur, micronutrients. 2.ed. New York, J. Wiley, 1999. 427p.

VIEIRA, F.C.B.; BAYER, C.; ZANATTA, J.A.; DIECKOW, J.; MIELNICZUK, J. \& HE, Z.L. Carbon management index based on physical fractionation of soil organic matter in an Acrisol under long-term no-till cropping systems. Soil Till. Res., 96:195-204, 2007.

ZOTARELLI, L.; ALVES, B.J.R.; URQUIAGA, S.; BODDEY, R.M. \& SIX, J. Impact of tillage and crop rotation on light fraction and intra-aggregate soil organic matter in two Oxisols. Soil Till. Res., 95:196-206, 2007. 